Литература

[1] Гостев В. И. Нечеткие регуляторы в системах автоматического управления [Текст] / В. И. Гостев // К.: «Радіоаматор», 2008. - 972 с.;

[2] Павлов А. И. Динамическая коррекция коэффициента передачи пропорционально-интегрального регулятора [Текст] / А. И. Павлов // Автоматизация технологических и бизнес-процессов. - Одесса, 2015. - V. 7. - № 1. C. 31-34.;

[3] Павлов А. И. Виртуальный стенд для определения оптимального по быстродействию исполнительного устройства [Текст] / А. И. Павлов // Автоматизация технологических и бизнес-процессов. - Одесса, 2014. - V. 6. - № 4. - С. 130-137.;

[4] Мюллер Ю. Регулирование на основе SIMATIC. Практическое пособие по регулированию [Текст] [пер. с нем. со 2-го изд.] / Ю. Мюллер, 2002. - 220 с.

References

[1] Gostev V. I. Nechetkiye regulyatory v sistemah avtomaticheskogo upravleniya [Tekst] / V. I. Gostev // K.: «Radioamator», 2008. - 972 str.;

[2] Pavlov A. I. Dinamicheskaya korrektsiya koeffitsienta peredachi proportsional'no-integral'nogo regulyatora [Tekst] / A. I. Pavlov // Avtomatizatsiya tekhnologicheskikh i biznes-protsessov. - Odessa, 2015. - V. 7. - № 1. - Str. 31-34.;

[3] Pavlov A. I. Virtual'niy stend dlya opredeleniya optimal'nogo po bystrodeystviyu ispolnitel'nogo ustroystva [Tekst] / A. I. Pavlov // Avtomatizatsiya tekhnologicheskikh i biznes-protsessov. - Odessa, 2014. - V. 6. - № 4. - Str. 130137.;

[4] Myuller Yu. Regulirovaniye na osnove SIMATIC. Prakticheskoye posobiye po regulirovaniyu [Tekst] [per. s nem. so 2-go izd.] / Yu. Myuller, 2002. - 220 str.

\title{
ЧАСТКОВЕ ОНОВЛЕННЯ - ІННОВАЦІЙНИЙ ІНСТРУМЕНТ УПРАВЛІННЯ ЕФЕКТИВНІСТЮ ФУНКЦІОНУВАННЯ УСТАТКУВАННЯ, ЩО ВІДРОБИЛО РЕСУРС
}

Partial renovating - the innovative tool of efficiency control of functioning of the equipment which has spent a resource

Воинова С. А., канд. техн. наук, доцент,

Одесская национальная академия пищевых технологий

E-mail: voinova_s@yahoo.com

ORCID ID: 0000-0003-0203-0599

Copyright (C 2014 by author and the journal “Automation technological and business - processes". This work is licensed under the Creative Commons Attribution International License (CC BY). http://creativecommons.org/licenses/by/4.0/

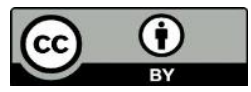


Анотація

Обернена увага на загострення проблеми оновлення технологічного устаткування, що витратило ресурс працездатності. Відмічено, що основна частина виробничих фондів країни складається 3 подібного, зношеного устаткування. Вказано на те, що подібне положення характерне для всіх галузей вітчизняного виробництва, включаючи харчову промисловість. Розглянуто основні задачі проблеми часткового оновлення зношеного устаткування, що дозволяс підвищити рівень його технологічної ефективності. Вказано комплекс робіт, що забезпечують технологію, конструкцію оновлюваного технічного об'єкту його технічне обслуговування. Цей комплекс складається 3 низки характерних організаційно-технічних завдань: обстеження стану зношеного устаткування, аналіз параметрів наміченого режиму його використання впродовж заданого майбутнього періоду його функціонування, розробка заходів оновлення, практична реалізація заходів програми, включаючи пуск в роботу і наладку, випробування його у дії, аналіз і оцінка результатів оновлення. Розглянуто особливості вирішення завдань проблеми в різних умовах і при різній мірі зносу. Відмічено, шо программа оновлення включає дві групи робіт: підвищення рівня технологічної ефективності функціонування устаткування, а також оновлення постановки процесу його експлуатації. Показано потенційні можливості часткового оновлення і доцільність його широкого застосування при нинішньому стані значної частини діючого вітчизняного устаткування. Підкреслено, що на кожному підприємстві існує певний резерв ресурсних можливостей щодо проведення програми оновлення доцільного об'єму. Вказано на можливість здобуття крупного комплексного позитивного ефекту при вирішенні завдань проблеми часткового оновлення зношеного технологічного устаткування.

\section{Abstract}

It is paid attention to an aggravation of a problem of renovating of the process equipment which has spent a resource of working capacity. It is noted, that the basic part of production assets of the country is consist of the

similar, worn out equipment. It is specified that similar position is characteristic for all branches of a domestic production, including food processing. The main tasks of a problem of partial renovating of the worn out equipment, allowing to raise a level of its technological efficiency are considered. The complex of the works providing technology, design of renovated technical object and its maintenance service is specified. This complex is consist of of some characteristic organizational-technical problems: inspection of a condition of the worn out equipment, the analysis of parameters of the planned mode of its use during the set future period of its functioning, development of means of renovating, practical realization of actions of programs i, including start-up in work and adjustment, its tests in operation, the analysis and an assessment of results of renovating. Features of the decision of problems of a problem in different conditions and at a different degree of wear of technical object are considered. Features of the decision of tasks of a problem in various conditions are considered and at a different measure of wear. It is noted, that the program of renovating includes two groups of works: increase of a level of technological efficiency of functioning of the equipment, and updating of statement of process of its operation. Potential of partial renovating and expediency of its wide appendix are shown at a current position of a major part of the operating domestic equipment. It is underlined, that at each enterprise there is a certain reserve of resource possibilities concerning carrying out of the program of updating of appropriate volume. It is specified a possibility of reception of large complex positive effect at the decision of tasks of a problem of partial renovating the worn out process equipment.

\section{Ключові слова}

Часткове оновлення, управління, технологічна ефективність функціонування, ресурс, зношене устаткування, технічний об'єкт.

Key words

Partial renovating, control, technological efficiency of functioning, the resource, the worn out equipment, technical object.

\section{Стан питання}

Стагнаційний період розвитку світового виробництва, що продовжується, підвищив до високого рівня долю діючих технічних об'єктів (ТО), що витратили ресурс працездатності. Рівень технологічної ефективності (ТЕ, Ет) процесу функціонування подібних зношених ТО невисокий, значно поступається показникам сучасного вітчизняного і зарубіжного устаткування аналогічного призначення. Характерним $є$ те, що подібне положення склалося і в енергетиці - галузі виробництва, приоритетно розвинутій [1]. 
Практично у всіх галузях виробництва сформувалася гостра проблема часткового оновлення, тобто підвищення рівня ТЕ, зношеного устаткування, підвищення рівня трьох її складових: екологічної, економічної і загальнотехнічної. У видимій перспективі, на шляху до майбутнього інноваційного періоду розвитку виробництва належить займатися вирішенням складних завдань вказаної проблеми. Необхідно підвищувати рівень ТЕ функціонування ТО (далі в тексті, скорочено: «ТЕ ТО»), тривало використовуваних, тому фізично і морально зношених. Тобто, необхідно здійснювати їх часткове оновлення. Вирішення проблеми часткового оновлення повинне йти паралельно із створенням нового інноваційно насиченого устаткування, яке повинне поступово витіснити і замінити собою зношене, застаріле устаткування. Така заміна є повним оновленням промислового устаткування. Доцільне вирішення проблеми часткового оновлення в принципі зводиться до вдосконалення підходу до управління станом ТО і технологічним процесом його функціонування [2].

Шляхи вирішення завдань проблеми часткового оновлення

При традиційному підході, створюючи новий ТО, конструктори заводу-виготівника вибирають для нього варіант технології і конструкції, виходячи з числа загальновідомих типових їх поєднань.

При прогресивному підході, замовник складає технічне завдання на створення нового ТО із зазначенням конкретних умов майбутнього його використання. Конструктори заводу-виготівника, стосовно умов замовника, вибирають з числа відомих кращу технологію і кращу конструкцію створюваного ТО і реалізують їх в виготовленому

на заводі новому ТО. Подібний ТО, створений згідно з прогресивним підходом, в умовах замовника має рівень ТЕ, що перевершує такий в аналогічних за призначенням об'єктах, створених відповідно традиційному підходу. Викладене характеризує принципові переваги прогресивного підходу перед традиційним [2].

Як зазначено вище, при існуючому, традиційному, підході, на заводі-виготівнику вибирають для створюваного ТО поєднання технології і конструкції, виготовляють ТО. Підприємство-замовник монтує у себе ТО,

розробляє, встановлюе, налаштовує і вводить в дію систему автоматичного управління (САУ) режимом функціонування об'єкту. У момент пуску цього ТО в дію він має вихідний, високий рівень ТЕ процесу функціонування (трьох її складових) [3]. Унаслідок зносу діючого ТО, з часом цей рівень знижується, оскільки ТО зазнає потенційний збиток ТЕ (викликаний його зносом), а також зазнає організаційний збиток (обумовлений використанням САУ, не адаптованої до змінних у часі, внаслідок зносу, властивостей ТО) [4].

У цих умовах часткове оновлення повинне містити комплекс робіт, що складається, в загальному випадку, 3 наступних частин:

а) вдосконалення елементів технології виробничого процесу, що протікає в ТО,

б) вдосконалення елементів конструкції ТО, САУ.

в) вдосконалення режиму функціонування ТО, шляхом підвищення якості процесу управління цим режимом з боку

Результат реалізації даного комплексу робіт є продуктивною керуючою дією на оновлюваний ТО, що забезпечує цільовий ефект - підвищення рівня його ТЕ. Окрім цього, частковому оновленню підлягає також система технічного обслуговування ТО.

Результат та перспективні можливості часткового оновлення

Технологічний ефект часткового оновлення полягає в підвищенні рівня ТЕ функціонування ТО за кожною 3 трьох його складових. При цьому, як випливає з досвіду, можливий ефект тим значніший, чим більший резервний запас працездатності (залишковий ресурс) оновлюваного ТО. Проте, в групі діючих однотипних ТО починати часткове оновлення доцільно з найбільш зношеного. Важливим ефектом оновлення є підвищення надійності ТО і ергономічних показників праці оперативного персоналу.

При проведенні часткового оновлення, слід прагнути до збереження споживчих властивостей ТО, закладених в нього заводом-виготівником. У полі уваги фахівців, що здійснюють програму оновлення, мають бути не тільки вказані вище три складові ТЕ, але і три складові соціальної ефективності ТО (рис. 1). Подальша експлуатація оновленого ТО має бути доступною і продуктивною за питомими ресурсовкладеннями в неї. Рівень якості показників процесу функціонування об'єкту має бути належно високим. Треба відзначити, що ресурсовкладення в підвищення кадрового потенціалу обслуговуючого персоналу впливає синергетично на приріст рівня ТЕ ТО, обумовлений доцільно проведеним оновленням.

Відмітимо, що міра ремонтопридатності ТО, закладена в нього заводом-виготівником, істотно позитивно впливає на питому вартість часткового оновлення. Важливою вимогою, що подається до вмісту програми оновлення, в загальному випадку, є забезпечення можливо більш значного підвищення, перш за все, рівня екологічної ефективності оновлюваного ТО. 
У загальному випадку використання зношеного устаткування, часткове оновлення є неминучим, вимушеним, але завжди економічно безумовно доцільним і виправданим етапом і об'єктом ресурсовкладення.

Розуміючи це, слід програму часткового оновлення робити максимально продуктивною. Нажаль, не всі власники зношеного устаткування обізнані про доступний резерв підвищення рівня його ТЕ, тому не компетентні у сфері продуктивного використання відомих позитивних можливостей часткового оновлення цього устаткування. У загальному випадку, часткове оновлення, організоване і здійснене належним чином, рентабельно. Воно знижує міру жорсткості існуючих у виробничих умовах організаційно-технічних ризиків різного роду, знижує ймовірність виникнення виробничих подій і потенційний збиток від дії їх наслідків.

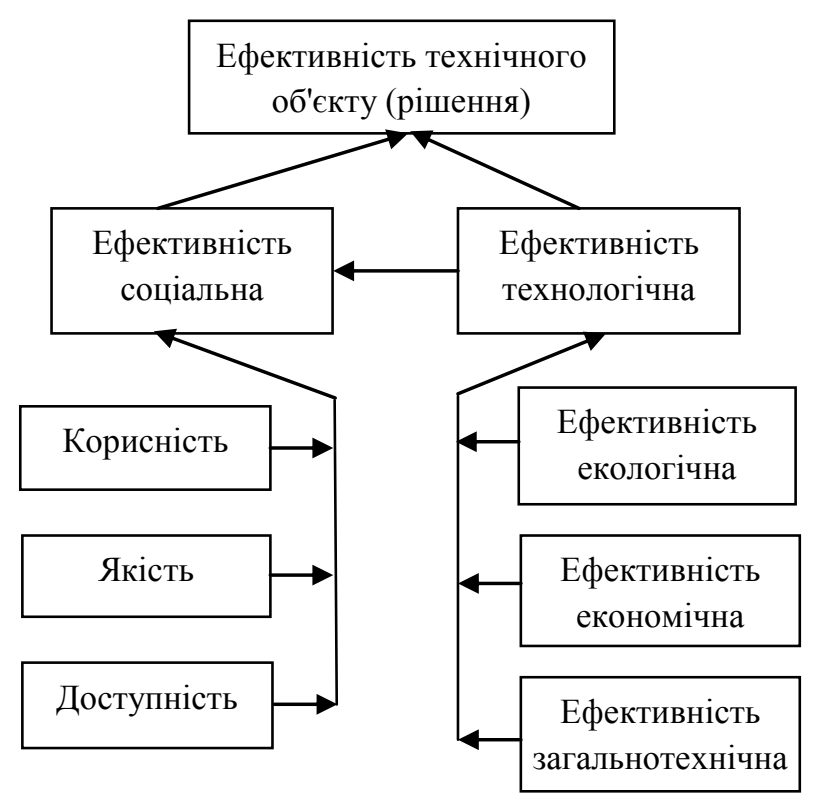

Рис. 1 - Структурно-логічна схема поняття «ефективність»

Оновлення торкається ТО, тобто технологічних агрегатів і їх допоміжного устаткування, функціональних схем виробничих ділянок, режимів функціонування устаткування, САУ, а також системи технічного обслуговування устаткування. Воно позитивно впливає на організаційно-адміністративну обстановку на підприємстві, обумовлює істотний позитивний соціальний ефект (рис. 2).

До складання і здійснення програми оновлення ТО слід притягати виконавців, що мають належно високу кваліфікацію і значний досвід роботи.

У підготовлену програму входять обстеження стану зношеного ТО, аналіз параметрів наміченого режиму його використання впродовж заданого майбутнього періоду його функціонування і розробка заходів оновлення. Далі здійснюється практична реалізація заходів програми, включаючи пуск в роботу і наладку оновленого ТО. Потім прямує випробування його у дії, дослідження і оцінка результатів оновлення.

В процесі роботи над програмою слід скласти баланс ТЕ оновленого ТО при його роботі в регулярному режимі $\mathrm{i}$ при прогнозованих відхиленнях від нього [5].

Істотною особливістю оновлення $\epsilon$ те, що найбільшою питомою ефективністю ресурсовкладення зазвичай відрізняється початковий етап робіт, що полягає в усуненні відхилень стану устаткування і прийомів його обслуговування від вимог прийнятого регламенту. Ця важлива обставина робить доцільним проведення часткового оновлення будь-якого об'єму, у тому числі малого.

Рівень потенційного ефекту залежить від виробничих умов використання ТО до і після здійснення його оновлення і дозволяє продовжувати на заданому відрізку часу подальшу експлуатацію ТЕ з підвищеним рівнем технологічних показників в порівнянні з їх рівнем до проведення оновлення. Таким чином, за допомогою часткового оновлення $\epsilon$ можливість впливати на ТЕ функціонування ТО, тобто управляти їі рівнем [6].

Очікувані наслідки оновлення

При належному, сучасному рівні постановки і здійснення програми часткового оновлення ТО може бути отримано позитивний ефект за усіма результатами цього складного комплексу заходів. 


\section{ТЕХНІЧНІ ЗАСОБИ ТА ТЕХНОЛОГІЇ В СИСТЕМАХ УПРАВЛІННЯ}

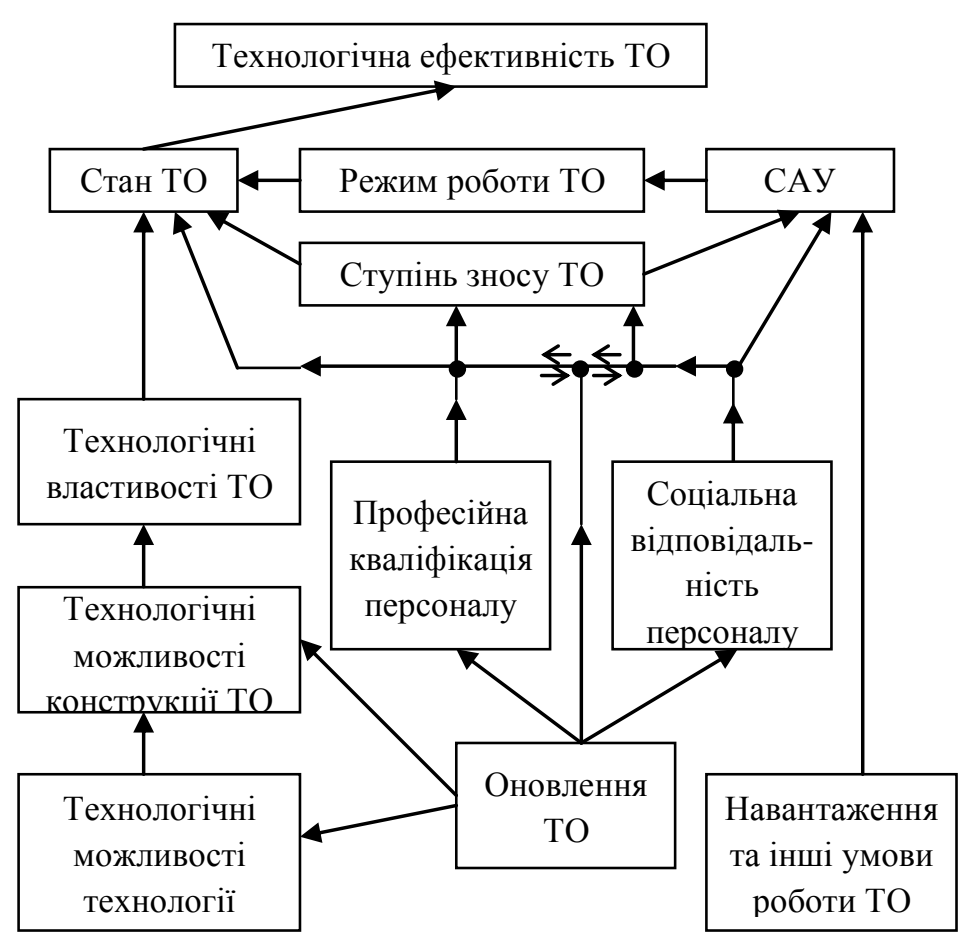

Рис. 2 - Структурно-логічна схема взаємодії чинників, які впливають на ТЕ функціонування ТО

Часткове оновлення ТО вирішує перше, технічне, завдання проблеми підвищення рівня ТЕ функціонування промислового устаткування. Друге завдання полягає в необхідності оновити постановку процесу експлуатації оновленого об'єкту, тобто жорстко забезпечити дотримання регулярного режиму його функціонування і регламентного технічного (експлуатаційного і ремонтного) обслуговування.

Важливе значення має якість процесу управління дією усіх елементів ії багаторівневої структурної організаційнотехнічної піраміди. Мається на увазі управління організацією, постановкою, проведенням і контролем над роботою як з боку замовника (власника оновлюваного ТО), так і з боку виконавця програми.

Виходячи з викладеного, є підстава вважати програму часткового (за об'ємом) і комплексного (за характером) оновлення зношених ТО інструментом інноваційного підходу до проблеми управління рівнем ТЕ функціонування зношеного промислового устаткування. Оновлення зношеного устаткування забезпечує отримання великого технологічного ефекту на підприємствах різних галузей виробництва, включаючи харчову промисловість України.

Слід особливо відмітити ту важливу обставину, що часткове оновлення зношеного устаткування є наріжним каменем концепції охорони природного середовища від наростаючої шкідливої антропогенної дії. В той же час, часткове оновлення гармонійно поєднується 3 соціальною i 3 економічною логікою розвитку виробництва i суспільства. Комплекс робіт по формуванню і по реалізації програми оновлення устаткування доцільно підпорядкувати системному підходу [7].

\section{Висновки}

1. У нинішньому вітчизняному виробництві значна частина ТЕ відпрацювала ресурс, тому підлягає оновленню.

2. У умовах, що склалися, доступним є часткове оновлення на основі використання доступних можливостей $\mathrm{i}$ ресурсовкладень.

3. У числі завдань оновлення провідне положення належить завданню підвищення екологічної ефективності оновлюваного ТО. Тому головна цінність програми часткового оновлення полягає в її середоохоронній суті.

4. За наявності на підприємстві декількох зношених однотипних ТО, визначення черговості проведення на них робіт по оновленню вимагає обліку показників стану кожного об'єкту. Першим серед них є стан ТО за провідним показником, за яким визначають ресурсні можливості об'єкту.

5. Належно здійснене часткове оновлення зношеного устаткування здатне забезпечити отримання значного позитивного соціального і технологічного (екологічного, економічного і загальнотехнічного) ефекту. 
6. Часткове оновлення дозволяє продуктивно підвищити рівень ТЕ функціонування зношеного устаткування на період вимушеного його використання, аж до повного оновлення - заміни новим.

7. Значні позитивні можливості часткового оновлення надають йому риси інноваційної вдачі.

8. Часткове оновлення зношеного устаткування - важливий вимушений аспект організації виробництва на завершальному етапі його розвитку за стагнаційним сценарієм.

9. У концепції оновлення зношеного устаткування часткове оновлення здатне стати важливим стартовим, відносно маловитратним етапом, що спрощує початковий етап майбутнього здійснення програми повного оновлення.

Література

[1] Теплова енергетика - нові виклики часу / За заг. редакцією П. Омеляновського, Й. Мисака. - Львів: НВФ «Українські технології», 2009.;

[2] Воинова С.А. О подходе к управлению технологической эффективностью создаваемых технических объектов / Міжнародний журнал «Автоматизація технологічних і бізнес-процесів», 2012, № 11, 12. - Одеса: ОНАХТ, 2012.- C. 26 - 28.;

[3] Воинова С.А. Об управлении эффективностью технологического оборудования, исчерпавшего ресурс / Міжнародний журнал «Автоматизація технологічних і бізнес-процесів», 2012, № 13, 14. - Одеса: ОНАХТ, 2013.- C. 15 - 19.;

[4] Воинова С.А. Некоторые особенности гибкого управления техническими объектами / Енергетика та електрифікація, 2013, № 10.- С. 34 - 37.;

[5] Воинова С.А. Баланс технологической эффективности технических объектов в регулярном режиме / Енергетика та електрифікація, 2014, №11.- С. 49 - 53.;

[6] Воинова С.А. Обновление как инструмент развития производства / Известия вузов и энергетических объединений СНГ, 2013, № 2.- С. 69 - 74.;

[7] Воінова С.О. Системний підхід до управління технологічною ефективністю технічних об'єктів / Труды 17-й Международной научно-технической конференции «Физические и компьютерные технологии», 20 - 21 сентября 2011г.- Харьков: ХНПК «ФЭД», 2011.- С. 105 - 108.

\section{References}

[1] Teplova energetika - novi vikliki chasu / Za zag. redaktsieyu P. Omelyanovskogo, Y. Misaka. - Lviv: NVF «Ukrayinski tehnologiyi», 2009.;

[2] Voinova S.A. O podhode k upravleniyu tehnologicheskoy effektivnostyu sozdavaemyih tehnicheskih ob'ektov / Mizhnarodniy zhurnal «Avtomatizatsiya tehnologichnih i biznes-protsesiv», 2012, № 11, 12. - Odesa: ONAHT, 2012.- S. 26 - 28.;

[3] Voinova S.A. Ob upravlenii effektivnostyu tehnologicheskogo oborudovaniya, ischerpavshego resurs / Mizhnarodniy zhurnal «Avtomatizatsiya tehnologichnih i biznes-protsesiv», 2012, № 13, 14. - Odesa: ONAHT, 2013.- S. 15 - 19.

[4] Voinova S.A. Nekotoryie osobennosti gibkogo upravleniya tehnicheskimi ob'ektami / Energetika ta elektriflkatsiya, 2013, № 10.- S. 34 - 37.;

[5] Voinova S.A. Balans tehnologicheskoy effektivnosti tehnicheskih ob'ektov v regulyarnom rezhime / Energetika ta elektrifIkatsiya, 2014, №11.- S. 49 - 53.;

[6] Voinova S.A. Obnovlenie kak instrument razvitiya proizvodstva / Izvestiya vuzov i energeticheskih ob'edineniy SNG, 2013, № 2.- S. 69 - 74.;

[7] Voinova S.O. Sistemniy pidhid do upravlinnya tehnologichnoyu efektivnistyu tehnichnih ob'ektiv / Trudyi 17-y Mezhdunarodnoy nauchno-tehnicheskoy konferentsii «Fizicheskie i kompyuternyie tehnologii», 20 - 21 sentyabrya 2011g.- Harkov: HNPK «FED», 2011.- S. 105 - 108. 